\title{
List of Original Publications
}

I would like to thank the following publication houses for granting the permission of reprinting the previously published articles as indicated in the following list of original publications: Bloomsbury, Brill, EOS Verlag, Finnish Exegetical Society, Finnish Oriental Society, Kohlhammer, Oriental Institute of the University of Chicago, Palgrave Macmillan, Peeters, Penn State University Press, Society of Biblical Literature, Ugarit-Verlag, and Vandenhoeck \& Ruprecht.

"Die Relevanz der neuassyrischen Prophetie für die alttestamentliche Forschung," in Mesopotamica - Ugaritica - Biblica, FS K. Bergerhof (ed. M. Dietrich and O. Loretz; AOAT 232, Kevelaer, Germany: Butzon \& Bercker; Neukirchen-Vluyn: Neukirchener, 1993) 217-58.

"Falsche Prophetie in neuassyrischer und deuteronomistischer Darstellung," in Das Deuteronomium und seine Querbeziehungen (ed. T. Veijola; PFES 62; Helsinki: Finnische Exegetische Gesellschaft and Göttingen: Vandenhoeck \& Ruprecht, 1996) 172-95.

"The Socioreligious Role of the Neo-Assyrian Prophets," in Prophecy in Its Ancient Near Eastern Context: Mesopotamian, Biblical, and Arabian Perspectives (ed. id.; SBLSymS 13; Atlanta, Ga.: Society of Biblical Literature, 2000) 89-114.

"City as Lofty as Heaven: Arbela and Other Cities in Neo-Assyrian Prophecy," in "Every City Shall Be Forsaken': Urbanism and Prophecy in Ancient Israel and the Near East (ed. L. L. Grabbe and R. D. Haak; JSOTSup 330; Sheffield: Sheffield Academic Press, 2001) $172-209$.

“A Prophetic Riot in Seleucid Babylonia,” in 'Wer darf hinaufsteigen zum Berg YHWHs?' Beiträge zu Prophetie und Poesie des Alten Testaments, Festschrift für Sigurður Örn Steingrimsson zum 70. Geburtstag (ed. H. Irsigler; Arbeiten zu Text und Sprache im Alten Testament 72; St Ottilien: EOS Verlag, 2002a) 62-74.

"Prophets and the Divine Council," in Kein Land für sich allein: Studien zum Kulturkontakt in Kanaan, Israel/Palästina und Ebirnâri für Manfred Weippert zum 65. Geburtstag (ed. U. Hübner and E. A. Knauf; OBO 186; Fribourg and Göttingen: Academic Press Fribourg and Vandenhoeck \& Ruprecht, 2002) 4-19.

"Das kritische Potential in der altorientalischen Prophetie," in Propheten in Mari, Assyrien und Israel (ed. M. Köckert and M. Nissinen; FRLANT 201; Göttingen: Vandenhoeck \& Ruprecht, 2003) 1-32.

"Fear Not: A Study on an Ancient Near Eastern Phrase," in The Changing Face of Form Criticism for the Twenty-First Century (ed. M. A. Sweeney and E. Ben Zvi; Grand Rapids, Mich.: Eerdmans, 2003) 122-61

"Neither Prophecies nor Apocalypses: The Akkadian Literary Predictive Texts," in Knowing the End from the Beginning: The Prophetic, the Apocalyptic and their Relationships (ed. L. L. Grabbe and R. D. Haak; JSPSup 46; London: T \& T Clark, 2003) 134-48.

(with S. Parpola) “Marduk's Return and Reconciliation in a Prophetic Letter from Arbela," in Verbum et calamus: Semitic and Related Studies in Honour of the Sixtieth Birthday of Professor Tapani Harviainen (ed. H. Juusola, J. Laulainen, and H. Palva; StOr 99; Helsinki: Finnish Oriental Society, 2004) 199-219. 
"What Is Prophecy? An Ancient Near Eastern Perspective," in Inspired Speech: Prophecy in the Ancient Near East, FS H. B. Huffmon (ed. J. Kaltner and L. Stulman; JSOTSup 372; London: T \& T Clark, 2004) 17-37.

"The Dubious Image of Prophecy", in Prophets, Prophecy, and Prophetic Texts in Second Temple Judaism (eds. M. H. Floyd and R. D. Haak; LHBOTS 427; New York / London: T \& T Clark, 2006) 26-41.

"From Holy War to Holy Peace: Biblical Alternatives to Belligerent Rhetoric," in Isaiah's Vision of Peace in Biblical and Modern International Relations: Swords into Plowshares (ed. R. Cohen and R. Westbrook; Culture and Religion in International Relations. New York: Palgrave Macmillan 2008) 181-97.

"Das Problem der Prophetenschüler," in Houses Full of All Good Things, GS T. Veijola (ed. J. Pakkala and id.; PFES 95; Helsinki: Finnish Exegetical Society, 2008) 337-53.

"Transmitting Divine Mysteries: The Prophetic Role of Wisdom Teachers in the Dead Sea Scrolls," in Scripture in Transition: Essays on Septuagint, Hebrew Bible, and Dead Sea Scrolls in Honour of Raija Sollamo (ed. A. Voitila and J. Jokiranta; JSJSup 126; Leiden: Brill, 2008) 513-33.

"Reflections on the 'Historical-Critical' Method: Historical Criticism and Critical Historicism," in Method Matters, FS D. L. Petersen (ed. J. M. LeMon and K. H. Richards; SBLRBS 56; Atlanta, Ga.: Society of Biblical Literature, 2009) 479-504.

"The Historical Dilemma of Biblical Prophetic Studies," in Prophecy in the Book of Jeremiah (ed. H. M. Barstad and R. G. Kratz; BZAW 388; Berlin: de Gruyter, 2009) 103-20.

"Wisdom as Mediatrix in Sirach 24: Ben Sira, Love Lyrics, and Prophecy," in Of God(s), Trees, Kings, and Scholars, FS S. Parpola (ed. M. Luukko, S. Svärd, and R. Mattila; StOr 106; Helsinki: Finnish Oriental Society 2009) 377-90.

"Pesharim as Divination: Qumran Exegesis, Omen Interpretation and Literary Prophecy," in Prophecy after the Prophets: The Contribution of the Dead Sea Scrolls to the Understanding of Biblical and Extra-Biblical Prophecy (ed. K. de Troyer and A. Lange; CBET 52; Leuven: Peeters, 2009) 43-60.

"Biblical Prophecy from a Near Eastern Perspective: The Cases of Kingship and Divine Possession," in Congress Volume, Ljubljana 2007 (ed. A. Lemaire; VTSup 133; Leiden: Brill, 2010) 441-68.

"Prophecy and Omen Divination: Two Sides of the Same Coin," in Divination and the Interpretation of Signs in the Ancient World (ed. A. Annus; Oriental Institute Seminars 6; Chicago: Oriental Institute, 2010) 341-51

"Comparing Prophetic Sources: Principles and a Test Case," in Prophecy and the Prophets in Ancient Israel (ed. J. Day ; LHBOTS 531; London: T \& T Clark, 2010): 3-24

"The Exiled Gods of Babylon in Neo-Assyrian Prophecy," in The Concept of Exile in Ancient Israel and Its Historical Contexts (ed. E. Ben Zvi and C. Levin; BZAW 404; Berlin: de Gruyter 2010) 27-38.

"Prophecy as Construct: Ancient and Modern," in "Thus Speaks Ishtar of Arbela": Prophecy in Israel, Assyria and Egypt in the Neo-Assyrian Period (ed. R. P. Gordon and

H. M. Barstad; Winona Lake, Ind.: Eisenbrauns, 2013) 11-35.

"The Prophet and the Augur at Tušhan, 611 B.C.," in Literature as Politics, Politics as Literature: Essays on the Ancient Near East in Honor of Peter Machinist (ed.

D. S. Vanderhooft and A. Winitzer; Winona Lake, Ind.: Eisenbrauns 2013) 329-337. 
"Prophets and Prophecy in Joshua-Kings: A Near Eastern Perspective," in Israelite Prophecy and the Deuteronomistic History: Portrait, Reality, and the Formation of History *(ed. M. R. Jacobs and R. F. Person; SBLAIL 14. Atlanta: Society of Biblical Literature 2013) $103-128$.

"Since When Do Prophets Write?," in In the Footsteps of Sherlock Holmes: Studies in the Biblical Text in Honour of Anneli Aejmelaeus (ed. K. de Troyer, T. M. Law and M. Liljeström; CBET 72. Leuven: Peeters 2014) 585-606.

"Sacred Springs and Liminal Rivers: Water and Prophecy in the Ancient Eastern Mediterranean," in Thinking of Water in Late Persian/Early Hellenistic Period in Judah (ed. E. Ben Zvi and C. Levin; BZAW 461; Berlin: Walter de Gruyter 2014) 29-48.

"Oracles at Qumran? Traces of Inspired Speakers in the Dead Sea Scrolls," in Crossing Imaginary Boundaries: The Dead Sea Scrolls in the Context of Second Temple Judaism (ed. M. S. Pajunen and H. Tervanotko; PFES 108. Helsinki: Finnish Exegetical Society, 2015) 165-181.

“(How) Does the Book of Ezekiel Reveal Its Babylonian Background?” WO 45 (2015) 85-98.

"The Book of Hosea and the Last Days of the Northern Kingdom: The Methodological Problem," in The Last Days of the Kingdom of Israel (ed. S. Hasegawa, C. Levin, and K. Radner; BZAW 511. Berlin: Walter de Gruyter, 2018) 369-382.

"Non-Male Prophets in Ancient Near Eastern Sources," in Prophets (ed. I. Fischer; Bible and Women 1.2.; Atlanta: SBL Press), forthcoming. 
